\title{
Diagnostic value of cerebrospinal fluid antibodies in herpes simplex virus encephalitis
}

\author{
MARJA-LEENA KOSKINIEMI, ANTTI VAHERI \\ From the Departments of Neurology and Virology, University of Helsinki, Helsinki, Finland
}

SUMMARY Antibodies to different viruses and bacteria were measured in the cerebrospinal fluid (CSF) of six patients with herpes simplex virus encephalitis proven by brain biopsy and in five others with a presumptive diagnosis. Antibodies to herpes simplex virus but not to other organisms appeared in the CSF of all patients after the first weeks of the illness. Herpes simplex virus antibodies were not found in control CSF. The antibodies persisted in the CSF and the serum/ CSF antibody ratio remained altered, $32: 1$ to $<1: 1$, in all cases during the follow-up to 29 months or until death. The CSF albumin level was normal and the IgG index $\left(\frac{\text { CSF IgG } \times \text { serum albumin }}{\text { serum IgG } \times \text { CSF albumin }}\right)$ elevated in four proven and three presumptive cases indicating a local antibody production; in four patients the findings were inconsistent. These results suggest that prolonged antigen stimulation is present in the central nervous system after acute herpes simplex encephalitis and that serological measurements combined with immunoglobulin and albumin determinations may provide a tentative but not definite diagnosis in some cases after the acute phase of encephalitis together with a method for follow-up of patients.

The diagnosis in herpes simplex encephalitis is important in view of the promising results obtained with vidarabine. ${ }^{1}$ Herpes simplex virus isolation from brain biopsy is the only reliable diagnostic means. ${ }^{2}$ However, a negative brain biopsy finding does not exclude herpes simplex virus encephalitis. $^{3}{ }^{4}$ It has been suggested that antibodies to herpes simplex virus in the cerebrospinal fluid and, in particular, an altered serum/CSF antibody ratio are diagnostic. ${ }^{5}$ We have studied the CSF antibody levels of six proven and five presumptive herpes simplex encephalitis patients. Complement fixing antibodies to the herpes simplex virus appeared in the CSF of all patients but not in the CSF of controls; they remained during the follow-up of 2 to 29 months or until death, and the serum/CSF antibody ratio remained altered.

\section{Patients and methods}

In six patients the diagnosis of herpes simplex encepha-

Address for reprint requests: Marja-Leena Koskiniemi MD, Department of Neurology, Kauniala Hospital for Disabled War Veterans, Kylpyläntie 19, 02700 Kauniainen, Finland.

Received 17 January 1981 and in revised form 20 October 1981

Accepted 1 November 1981 litis was considered proven and was based on isolation of the virus in brain biopsy or demonstration of viral antigen in brain biopsy in association with characteristic histopathology (table 1). In five additional patients the diagnosis was presumptive and based on clinical features, characteristic neurophysiological and neuroradiological findings, and exclusion of other diseases. All patients showed focal unilateral or bilateral temporal lesions as judged by electroencephalography, computed tomography (not done in case 1), or carotid arteriography (not done in cases 4-6). Adenine arabinoside (vidarabine, Vira-A), $10-15 \mathrm{mg} / \mathrm{kg}$ weight/day was administered as an intravenous infusion to nine patients (1 to 9); in two of them (2 and 7) the 10-day therapy was repeated. Interferon 3 million units twice daily was administered to three patients $(5,6$, and 11$)$ for two to four weeks. All patients received dexamethasone intramuscularly in decreasing doses for 10 days.

The control group consisted of 39 adult patients with miscellaneous neurological symptoms (headache, vertigo, paraesthesia) and of five patients with diagnostic brain biopsy (Mycoplasma pneumoniae encephalitis, meningococcal meningoencephalitis, influenza A encephalitis, intracerebral abscess, encephalitis of unidentified aetiology).

Serum and CSF antibodies were measured by the complement fixation (CF) test using antigens specific to adeno-, corona-, Coxsackie B5, cytomegalo-, hepatitis B, herpes simplex, influenza $\mathbf{A}$, influenza $\mathbf{B}$, measles, mumps, parainfluenza type 1, parainfluenza type 3, polio, 
Table 1 Clinical data and brain biopsy findings in patients. Patients 1 and 6 are considered proven and 7 to 11 presumptive cases of herpes simplex virus encephalitis

\begin{tabular}{|c|c|c|c|c|}
\hline \multirow[t]{2}{*}{ Patient } & \multirow[t]{2}{*}{ Age/sex $(y r)$} & \multicolumn{2}{|l|}{ Brain biopsy } & \multirow{2}{*}{$\frac{\text { Outcome }}{\text { (Follow-up period) }}$} \\
\hline & & Days after onset of symptoms* & Positive findings & \\
\hline 1 & $51 / M$ & 7 & HSV isolation & $\begin{array}{l}\text { Died } \\
\text { (71 days) }\end{array}$ \\
\hline 2 & $68 / F$ & 7 & $\begin{array}{l}\text { HSV isolation } \\
\text { HSV antigen }\end{array}$ & $\begin{array}{l}\text { Died } \\
\text { (18 months) }\end{array}$ \\
\hline 3 & $26 / F$ & 7 & $\begin{array}{l}\text { HSV antigen } \\
\text { Intranuclear inclusions }\end{array}$ & $\begin{array}{l}\text { Gait disorder } \\
\text { Severe mental defect } \\
\text { ( } 28 \text { months) }\end{array}$ \\
\hline 4 & $68 / \mathrm{F}$ & 7 & $\begin{array}{l}\text { HSV isolation } \\
\text { HSV antigen } \\
\text { Intranuclear inclusions }\end{array}$ & $\begin{array}{l}\text { Died } \\
\text { (30 days) }\end{array}$ \\
\hline 5 & $38 / F$ & 10 & $\begin{array}{l}\text { HSV isolation } \\
\text { HSV antigen }\end{array}$ & $\begin{array}{l}\text { Moderate mental defect } \\
\text { ( } 2 \text { months) }\end{array}$ \\
\hline 6 & $55 / \mathrm{M}$ & 15 & $\begin{array}{l}\text { HSV antigen } \\
\text { Necrosis, gliosis }\end{array}$ & $\begin{array}{l}\text { Died } \\
\text { (42 days) }\end{array}$ \\
\hline 7 & $53 / \mathrm{F}$ & 59 & $\begin{array}{l}\text { Necrosis } \\
\text { Inflammation }\end{array}$ & $\begin{array}{l}\text { Mildly incapacitated } \\
\text { ( } 29 \text { months) }\end{array}$ \\
\hline 8 & $49 / \mathrm{M}$ & Not done & & $\begin{array}{l}\text { Severe mental defect } \\
\text { ( } 21 \text { months) }\end{array}$ \\
\hline 9 & $30 / \mathbf{M}$ & Not done & & $\begin{array}{l}\text { Mildly incapacitated } \\
\text { (6 months) }\end{array}$ \\
\hline 10 & $77 / F$ & 23 & $\begin{array}{l}\text { Necrosis } \\
\text { Inflammation }\end{array}$ & $\begin{array}{l}\text { Died } \\
\text { (72 days) }\end{array}$ \\
\hline 11 & $43 / F$ & Not done & & $\begin{array}{l}\text { Severe mental defect } \\
\text { (13 months) }\end{array}$ \\
\hline
\end{tabular}

*Referring to brain involvement.

respiratory syncytial, rota and varicella viruses, and to Chlamydia, Mycoplasma pneumoiae and Toxoplasma gondii. Herpes simplex antigen was prepared from African green monkey kidney cell cultures (Vero) infected with herpes simplex virus type 1 , a locally isolated strain. Measles, parainfluenza type 1 and respiratory syncytial virus $C F$ antigens were also prepared in Vero cell cultures and thus served as virus-infected control antigens. In addition, if a specimen gave positive reaction to many antigens, specifically prepared control antigens from uninfected cell cultures were always included in the test series.

To evaluate the function of the blood-brain barrier and the local antibody production within the central nervous system, serum and CSF albumin and immunoglobulin levels were measured by automated fluoronephelometry (Technicon Autoanalyzer) and the IgG index was calculated using the formula

$$
\left(\frac{\mathrm{CSF} \text { IgG } \times \text { serum albumin }}{\text { serum IgG } \times \mathrm{CSF} \text { albumin }}\right) \cdot{ }^{6}
$$

In addition, routine bacteriological cultures, virus isolations, immunofluorescence test for detection of cellular herpes simplex antigen and cytological examinations were performed from the CSF. All these latter studies gave negative results with respect to specific diagnosis.

\section{Results}

Herpes simplex antibodies were detected in the CSF in one patient 8 days and in two patients 11-12 days after the onset of symptoms (table 2). After the first month of illnes herpes simplex antibodies in the CSF were present in all survivors with either proven or presumptive herpes simplex encephalitis. One patient (5) had a titre (all titres are given as reciprocal values) of 8 to varicella zoster in the CSF 47 days after the onset of herpes simplex encephalitis, concurrently the titre to herpes simplex virus was 32 and one (7) a titre of 2 to varicella zoster on day 72 . No other positive titres of antibodies to other organisms were found in the CSF; serum titres ranged up to 64 . $A \geqslant$ four-fold increase in herpes simplex virus titres in the CSF was seen in five and decrease in two of the patients. Herpes simplex antibodies in the CSF persisted during the follow-up in all patients and exceeded serum levels in one of them. Serum/CSF herpes simplex antibody ratio ranged from $32: 1$ to $<1: 1$. The ratio remained altered during the follow-up period.

The CSF albumin level in five patients $(2,4,6,8,9)$ appeared normal (reference value $82-290 \mathrm{mg} / \mathrm{l}$ ), in four $(1,3,5,11)$ a normalisation occurred at least transiently, and in two $(7,10)$ the level remained above the normal range (table 2 ).

The IgG index in the CSF ranged from 0.51 to $3 \cdot 38$ (reference value $0 \cdot 34-0 \cdot 58$ ). In one proven case (4), though within the normal range, the index approached the upper limit.

In the controls, one brain biopsied patient showed a titre of 2 to influenza $A$ in the CSF; simultaneous serum level was 256 . No further complement fixing 
Table 2 Cerebrospinal fluid herpes simplex antibodies, albumin, and $\operatorname{Ig} G$ index $\left(\frac{C S F \operatorname{Ig} G \times \text { serum albumin }}{\operatorname{serum} \operatorname{Ig} G \times C S F \text { albumin }}\right)$ and ratio of serum/CSF antibodies

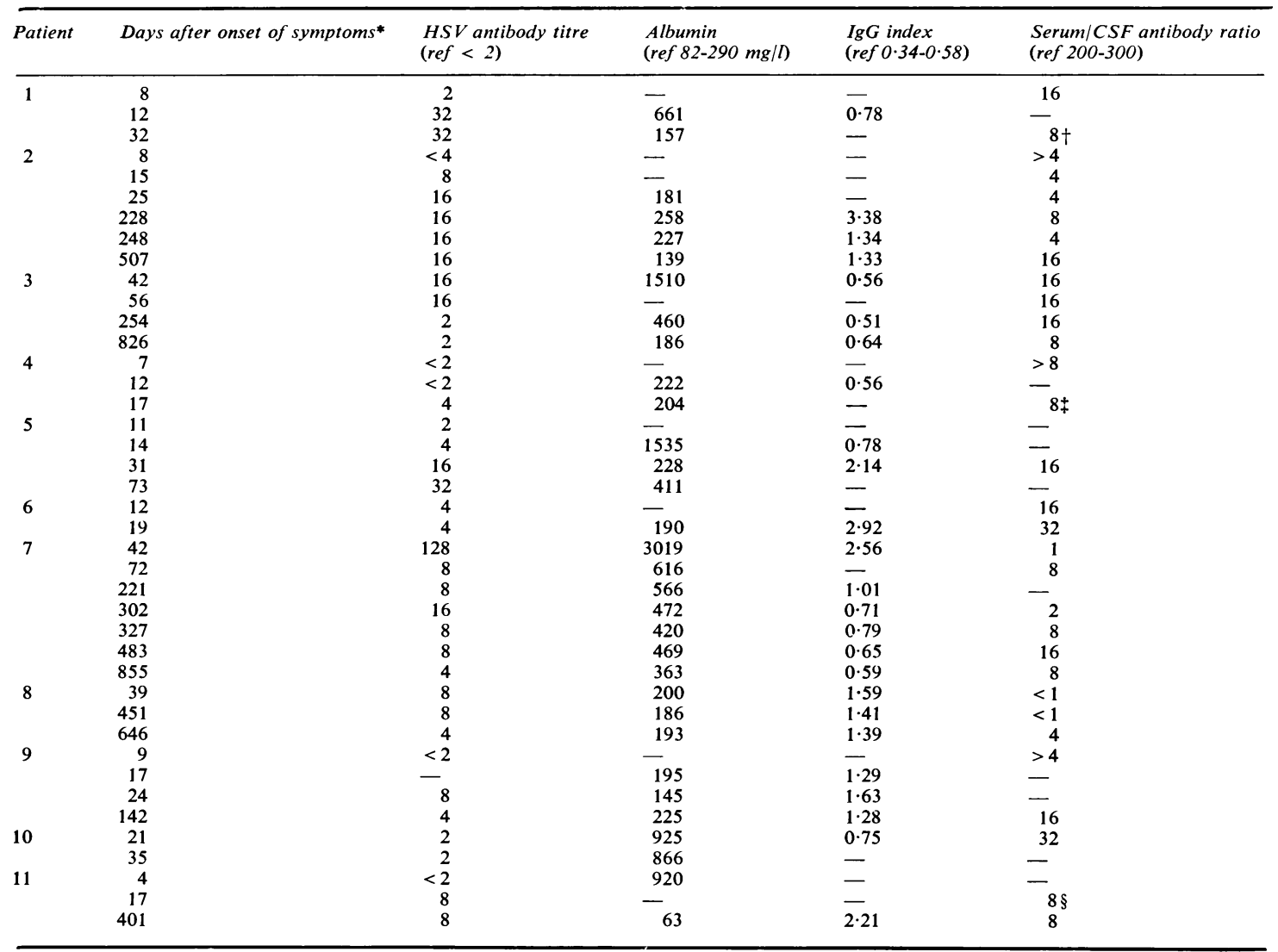

*Referring to brain involvement. † † $\quad$ Serum level 256 from day 29.

antibodies were detected in the CSF of the 44 control patients. Serum titres ranged up to 256 . The albumin levels in the CSF ranged from 90 to 249 $\mathrm{mg} / \mathrm{l}$ and the IgG index from $0 \cdot 27$ to $0 \cdot 60$.

\section{Discussion}

Antibodies to herpes simplex virus appeared in the cerebrospinal fluid of all six patients with brain biopsy proven herpes simplex encephalitis while they were not detected in the CSF of the five control patients with diagnostic brain biopsy, or in any of the further 39 control patients. During the course of the disease, $a \leqslant$ four-fold rise in antibody titre was shown in three patients with proven herpes simplex encephalitis. In one, an eight-fold decrease in titre occurred. In five patients with presumptive herpes simplex encephalitis, two of whom were $\ddagger$ Serum level 32 from day 21 . $\$$ Serum level $<8$.

brain biopsied but only histopathological confirmation of herpes simplex encephalitis was obtained, the CSF antibody titres were similar to those in the proven cases. The specificity of determination appeared high because only two patients showed antibodies to other viruses in the CSF; antibodies to varicella zoster appeared in patients 5 and 7 . This may be due to cross-reactivity between the different herpes viruses. These findings suggest that measurement of CSF herpes simplex antibody level with the complement fixation test may be of interest when brain biopsy is performed later (in the present cases 7 and 10,59 and 23 days after the onset of the disease) and virus is not recovered. In early diagnosis, which in herpes simplex encephalitis is of great importance and can be obtained by brain biopsy only, determination of CSF complement fixation antibodies is of little value. In the 
present series, five CSF specimens were available from days 4 to 9 after the onset of symptoms and only one of them (from day 8) showed herpes simplex antibodies with the complement fixation test. However, it should be emphasised that herpes simplex antibody determination alone is of limited value.

The serum/CSF ratio was altered, from $32: 1$ to $<1: 1$, in all herpes simplex encephalitis patients, and it remained abnormal during the follow-up period up to 29 months. However, a defect in the blood-brain barrier may cause increased antibody leakage into CSF spaces as is reported to occur in bacterial meningitis, ${ }^{7}$ and alter the serum/CSF antibody ratio. The appearance of herpes simplex, but not other antibodies, in the CSF contradicts the idea of antibody leakage. In the present study the serum antibody levels to other organisms were all relatively low $(\leqslant 64)$; thus the serum/CSF ratios for these antibodies may not be adequately calculated.

CSF albumin is a sensitive indicator of the function of the blood-brain barrier. In the present series a large variation of albumin levels appeared in herpes simplex encephalitis cases. In case 7 a huge albumin leakage was observed at the same time that IgG index was highly abnormal. A normal albumin concentration, transiently at least, was found in all proven and in three presumptive herpes simplex encephalitis patients at the time when herpes simplex antibodies were detected in the CSF. The possibility of central production of herpes simplex antibodies is thus strengthened. The kinetics of the CSF titres to herpes simplex virus also suggests local antibody production. Further support was obtained, when the IgG index, which is shown to measure immunoglobulin production in the central nervous system, ${ }^{6}$ was determined. Four proven and three presumptive herpes simplex encephalitis patients in the present series $(2,3,5,6,8,9,11)$ showed elevated IgG indices and normal albumin levels in the CSF. Thus the central origin of CSF JgG seems apparent. How large a portion of this IgG is specific for herpes simplex virus related antigens is not known. That IgG molecules with other specificities are produced seems likely. In our proven herpes simplex encephalitis case 6 , for instance, the herpes simplex antibody titre in the CSF was only 4 but the IgG index was indicative of massive central immunoglobulin production.
The persistence of herpes simplex antibodies in the CSF of all cases was conspicuous. The persisting or even increasing antibody level in the CSF suggests a continuous antigenic stimulation in central nervous system. Thus herpes simplex encephalitis may have a chronic course, which is suggested by clinical findings, too. ${ }^{8}$

Simultaneous determination of serum and CSF herpes simplex antibodies may provide suggestive diagnostic evidence in herpes simplex encephalitis but more information is obtained by simultaneous measurements of antibody and albumin levels and of the IgG index in the CSF. It is difficult to assess the definitive diagnostic value of herpes simplex antibody determinations, however, with the limited information currently available about the specificities of the immunoglobulins centrally produced in herpes simplex encephalitis.

We thank Mrs Pirkko Koivunen for her assistance. This study was supported by grants from the Finnish Medical Research Council and the Association of Finnish Life Assurance Companies.

\section{References}

${ }^{1}$ Whitley RJ, Soong SJ, Dolin R, et al. Adenine arabinoside therapy of biopsy-proved herpes simplex encephalitis. New Engl J Med 1977;297:289-94.

2 Johnson RT, Olson LC, Bueschner EL. Herpes simplex virus infections of the nervous system: problems in laboratory diagnosis. Arch Neurol 1968;18:260-4.

${ }^{3}$ Nagington J, Rubenstein D, Anderson J. Herpes simplex encephalitis. Lancet 1976;1:493.

4 Adams JH, Jennett B. Acute necrotizing encephalitis: a problem in diagnosis. J Neurol Neurosurg Psychiatry 1967;30:248-59.

${ }^{5}$ Levine DP, Lauter OB, Lerner AM. Simultaneous serum and CSF antibodies in herpes simplex virus encephalitis. JAMA 1978;240:356-60.

${ }^{6}$ Delpech B, Lichtblau E. Etude quantitative des immunoglobulins $\mathrm{G}$ et de l'albumine du liquide cephalo rachidien. Clin Chem Acta 1972;37:15-23.

7 Winchester JS, Hambling MH. Antibodies to measles, mumps, and herpes simplex virus in cerebrospinal fluid in acute infections and postinfectious diseases of the central nervous system. J Med Microbiol $1972 ; 5: 137-43$.

${ }^{8}$ Williams BB, Lerner AM. Some previously unrecognized features of herpes simplex virus encephalitis. Neurology (NY) 1978;28:1193-6. 